Creative commons User License: CC BY-NC-ND

Abstracted by: EBSCOhost, Electronic Journals Service (EJS),

Google Scholar, Journal Seek, Scientific Commons,

Food and Agricultural Organization (FAO), CABI and Scopus
Journal of Agricultural Extension

Vol. 22 (2) June, 2018

ISSN(e): 24086851; ISSN(Print); 1119944X

http://journal.aesonnigeria.org

http://www.ajol.info/index.php/jae

Email: editorinchief@aesonnigeria.org

\title{
Socio-Economic Factors and Profitability of Groundnut Processing by Women in
}

Kano State, Nigeria https://dx.doi.org/10.4314/jae.v22i2.1

\section{Shuaibu, $\mathbf{H}$.}

Department of Agricultural Extension and Rural Development, Faculty of Agriculture/Institute for Agricultural Research, Ahmadu Bello University, Zaria, Nigeria.

Corresponding author: hskugu@yahoo.com ; +2347031187744

\section{Akinola, M. 0.}

Department of Agricultural Extension and Rural Development, Faculty of Agriculture/Institute for Agricultural Research, Ahmadu Bello University, Zaria, Nigeria.

Akpoko, J. G.

Department of Agricultural Extension and Rural Development, Faculty of Agriculture/Institute for Agricultural Research, Ahmadu Bello University, Zaria, Nigeria.

\section{Damisa, M. A.}

Department of Agricultural Economics, Faculty of Agriculture/Institute for Agricultural Research, Ahmadu Bello University, Zaria, Nigeria.

Yakubu, D. H.

Department of Agricultural Extension and Rural Development, Faculty of Agriculture, Usman Danfodiyo University, Sokoto, Nigeria.

\section{Abstract}

The study assessed the effect of socio-economic factors on profitability of groundnut processing into groundnut cake and oil by women in Kano State, Nigeria. A multi-stage sampling procedure was employed to select 298 respondents. Data collected for the study include information on socio-economic characteristics, and profit from enterprise. The tools of the analysis employed for data interpretation were descriptive statistics, and multiple regression analysis. Findings revealed that age $(\beta=165.822, P<0.05)$, household size $(\beta=$ 464.540, $P<0.05)$, years of formal education $(\beta=-2016.520, P<0.01)$, years of membership in cooperative $(\beta=610.86, P<0.10)$, nature of involvement in enterprise $(\beta=5002.815$, $P<0.01)$, ownership structure $(\beta=-5064.77, P<0.05)$ and access to market $(\beta=3009.693$, $P<0.05)$ significantly influenced profitability of groundnut processing to cake and oil. The major problems militating against the women were inadequate capital and high cost of raw materials. It was concluded that groundnut processing was profitable and some social, institutional and enterprise characteristics influence level of the profit realized. The recommendations put for the study were that the women should be enlightened by extension personnel to form cooperatives that will assist in linking the women to for better access to credit, improved equipment, information and other extension benefits on groundnut processing so as to enhance the ease of production.

Keywords: Women processors, Groundnut processing, Groundnut cake, Groundnut oil 
Creative commons User License: CC BY-NC-ND

Abstracted by: EBSCOhost, Electronic Journals Service (EJS),

Google Scholar, Journal Seek, Scientific Commons,

Food and Agricultural Organization (FAO), CABI and Scopus
Journal of Agricultural Extension

Vol. 22 (2) June, 2018

ISSN(e): 24086851; ISSN(Print); 1119944X

http://journal.aesonnigeria.org

http://www.ajol.info/index.php/jae

Email: editorinchief@aesonnigeria.org

\section{Introduction}

Groundnut, or peanut, commonly called the poor man's nut is an important oilseed and food crop for millions of people in the semi-arid tropics. It generates employment on the farm during cultivation and during processing (CGIAR, 2005). A report by FAO in 2009 revealed that groundnut on an average is grown on 26.4 million hectares worldwide with a total production of 36.1 million metric tonnes, and an average yield of 1.4 metric tons/ha (FAO, 2009). According to FAOSTAT (2011) and Girei et al. (2013), groundnut is grown in nearly 100 countries with China, India, U.S.A, Indonesia, Nigeria, Myanmar and Sudan as major producers. Nigeria is one of the world's largest groundnut producers, accounting for $10 \%, 39 \%$ and $51 \%$ of the total world's, Africa's and West Africa's groundnut production, respectively (ICRISAT, 2011). Total production accounted for $70 \%$ of Nigeria's total export prior to petroleum oil boom (IFPRI, 1994 in Girei et al., 2016).

Groundnut is important both as a cash crop and food crop. It is the $13^{\text {th }}$ most important food crop of the world and the $4^{\text {th }}$ most important source of edible oil. Its seeds contain high quality edible oil (50\%), 40-50\% protein and $10-20 \%$ carbohydrates (Taphee and Jongur, 2014). Groundnut kernels are consumed directly as raw, roasted, salted or boiled forms. However, oil is the most important product of the crop which is used for both domestic and industrial purposes. The crop is used as industrial materials for producing oil-cakes and fertilizer. All parts of the groundnut plant are used in one way or the other (Nnamdi, 2010).

Though there is little participation of women in groundnut production activities, they are strongly involved in local groundnut processing activities. In Nigeria, the processing of groundnut into various products is mostly done by women either for home consumption or for commercial purposes (Ibrahim et al., 2005 in Ibrahim et al., 2010). The processing of groundnut is both a source of income and employment to a large proportion of rural women in northern Nigeria. Groundnut processing is basically the transformation of the primary agricultural products (raw groundnut) into other finished commodities like groundnut oil, cake and animal feed among others. Processing of groundnut is perhaps the best area an investor can engage in with maximum utilization of the product. The milling of the product would yield edible oil which can be refined to get vegetable oil and groundnut cake which is a valuable input in the preparation of animal feed and as such can be sold to animal feed millers. Groundnut processing in the study area reduces food wastage, enhances food security, improvement in livelihood of low income groups and empowerment of women especially in Nigeria where processing of groundnuts into various products is mostly done by women either for home or commercial consumption (Practical Action, 2010).

Past studies (Danwanka et al., 2005; Haruna et al., 2006; Muhammad-lawal et al., 2012) reported that groundnut processing activity is profitable; however, the profit level realized has been relatively low. The low profit level could be attributed to many factors which could be economic, social, institutional and/or enterprise related. It is therefore, 
Creative commons User License: CC BY-NC-ND

Abstracted by: EBSCOhost, Electronic Journals Service (EJS),

Google Scholar, Journal Seek, Scientific Commons,

Food and Agricultural Organization (FAO), CABI and Scopus
Journal of Agricultural Extension

Vol. 22 (2) June, 2018

ISSN(e): 24086851; ISSN(Print); 1119944X

http://journal.aesonnigeria.org

http://www.ajol.info/index.php/jae

Email: editorinchief@aesonnigeria.org

worthwhile to study the determining factors that influence the profitability in order to look into possible ways and means (policy formulation) that will enhance profitability of the enterprise. The study addressed the following objectives:

1. described the socioeconomic characteristics of women processors;

2. identified the constraints that militate against realization of profit; and

3. determined the factors that influence profitability of groundnut processing of women in the study area.

\section{Methodology}

Kano State is located in North-Western Nigeria. The State is situated in a semi-arid region located between latitudes $10^{\circ} 30^{\prime}$ and $13^{\circ} 02^{\prime}$ north of the equator and longitude $7^{\circ} 40^{\prime}$ and $10^{\circ} 39^{\prime}$ east of the Greenwich meridian. It has 44 local government areas which are divided into three agricultural zones. Kano State has a 2015 projected population (based on the 2006 National Population Census) of 10,067,208 people with an almost equal distribution of males (51\%) and females (49\%) (National Population Commission, 2006). Agriculture is the mainstay of the economy involving at least $75 \%$ of the rural population. Before the oil boom of 1970 s, Kano State was the main producer of groundnut (producing at least $50 \%$ of the country total output).

A multi-stage sampling technique was employed. In the first stage, the three agricultural zones of the state were all selected for the study then four registered groups out of the six registered women groundnut processors in each zone were randomly selected and finally all 25 members of each group were used for the survey to give a total sample size of 298 respondents.

Data were collected using a structured questionnaire which was administered to the respondents by the researcher with the help of trained enumerators between February and April, 2015. The instrument was subjected to content and face validity. Furthermore, a pre-test with 10 selected rural women in the study area was also conducted. Thus, necessary additions, deletions, modifications and adjustments were made in the questionnaire. Data collected for the study were analysed with descriptive statistics and multiple regression analysis described below:

$Y=\beta_{0}+\beta_{1} X_{1}+\beta_{2} X_{2}+\ldots \ldots \ldots \ldots \ldots \ldots \ldots+\beta_{13} X_{13}+u$

Where:

$Y=$ Profit from groundnut processing (naira).

$\mathrm{X}_{1}-\mathrm{X}_{13}=$ are independent variables defined as:

$\mathrm{X}_{1}=$ age of woman (in years)

$\mathrm{X}_{2}=$ years of formal education

$X_{3}=$ household size (number)

$\mathrm{X}_{4}=$ marital status (married $=1$, otherwise $=0$ )

$X_{5}=$ Headship status (Female headed $=1$, Male headed $=2$ ) 
Creative commons User License: CC BY-NC-ND

Abstracted by: EBSCOhost, Electronic Journals Service (EJS),

Google Scholar, Journal Seek, Scientific Commons,

Food and Agricultural Organization (FAO), CABI and Scopus
Journal of Agricultural Extension

Vol. 22 (2) June, 2018

ISSN(e): 24086851; ISSN(Print); 1119944X

http://journal.aesonnigeria.org

http://www.ajol.info/index.php/iae

Email: editorinchief@aesonnigeria.org

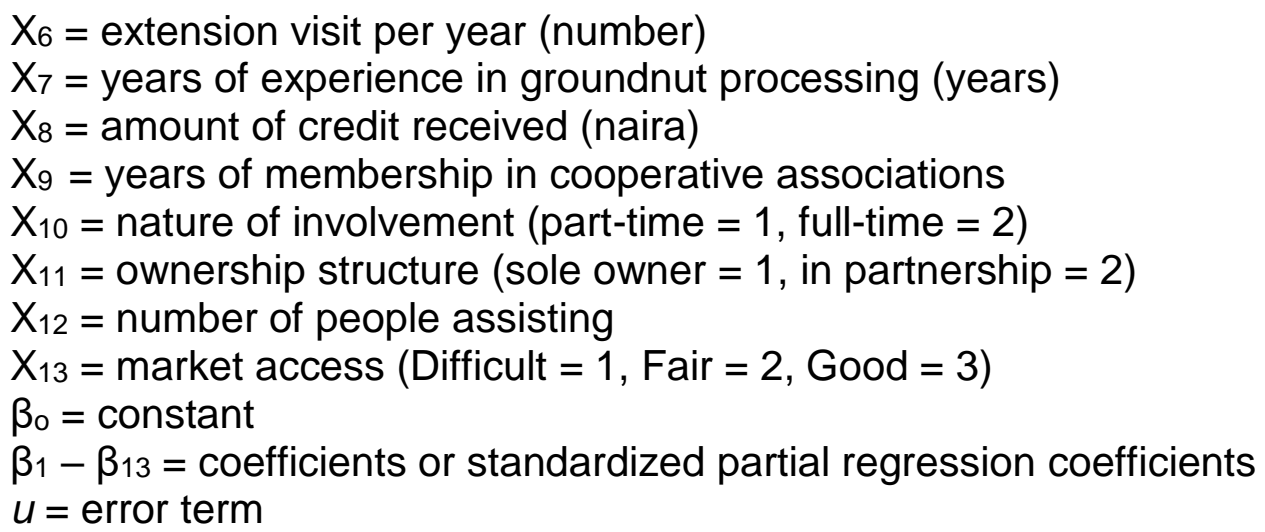

\section{Results and Discussion}

\section{Socio-economic Characteristics of Women Groundnut Processors}

Table 1 shows the socioeconomic characteristics of women groundnut processors in the study area. Age of the women ranged from 21 to above 60 years with a mean of about 40 years. This means that the respondents are still in their active and productive age thus possess the energy needed to carry out income earning activities for improved household welfare. As this study was undertaken in northern part of Nigeria, it is not surprising that majority (94\%) of the respondents were married and about $64 \%$ do not have any form of formal education. Of the total sampled households, about $94 \%$ were male-headed with mean household size of 12 indicating a large household which is not unexpected in this part of the country where many polygamous homes exist. The finding is similar to that of other researchers (Abonge, 2012; Nwosu and Okon, 2013; Abdullahi et al., 2014), in separate studies that the majority (ranging from $50-95 \%$ ) of rural women agro-processors were married and Jamilu et al. (2014) that rural households in Kaduna State have an average of 11 members. 
Creative commons User License: CC BY-NC-ND

Abstracted by: EBSCOhost, Electronic Journals Service (EJS),

Google Scholar, Journal Seek, Scientific Commons,

Food and Agricultural Organization (FAO), CABI and Scopus
Journal of Agricultural Extension

Vol. 22 (2) June, 2018

ISSN(e): 24086851; ISSN(Print); 1119944X

http://journal.aesonnigeria.org

http://www.ajol.info/index.php/jae

Email: editorinchief@aesonnigeria.org

\section{Table 1: Socioeconomic characteristics of the respondents}

\begin{tabular}{|c|c|}
\hline Variables & Percentage \\
\hline \multicolumn{2}{|l|}{ Age (years) } \\
\hline $21-40$ & 57.1 \\
\hline $41-60$ & 41.6 \\
\hline above 60 & 1.3 \\
\hline Mean & 40 \\
\hline \multicolumn{2}{|l|}{ Marital Status } \\
\hline Married & 94.0 \\
\hline Otherwise & 6.0 \\
\hline \multicolumn{2}{|c|}{ Educational Qualification (years) } \\
\hline No formal Educational & 63.8 \\
\hline $1-6$ & 26.2 \\
\hline $7-12$ & 10.0 \\
\hline Mean & 2 \\
\hline \multicolumn{2}{|l|}{ Household headship } \\
\hline Male-headed & 94.0 \\
\hline Female-headed & 6.0 \\
\hline \multicolumn{2}{|l|}{ Household size } \\
\hline $1-5$ & 11.4 \\
\hline $6-10$ & 36.4 \\
\hline $11-15$ & 27.4 \\
\hline $16-20$ & 16.3 \\
\hline Above & 8.5 \\
\hline Mean & 12 \\
\hline \multicolumn{2}{|l|}{ Extension visits } \\
\hline No visit & 43.3 \\
\hline 1 & 50 \\
\hline 2 & 6.7 \\
\hline Mean & 1 \\
\hline \multicolumn{2}{|c|}{ Years of experience (years) } \\
\hline$<11$ & 35.6 \\
\hline $11-20$ & 53.4 \\
\hline $21-30$ & 9.7 \\
\hline $31-40$ & 1.3 \\
\hline Mean & 13 \\
\hline \multicolumn{2}{|l|}{ Access to credit } \\
\hline No access & 89.6 \\
\hline Had access & 10.4 \\
\hline \multicolumn{2}{|c|}{ Membership of association (years) } \\
\hline None & 19.1 \\
\hline $1-10$ & 57.4 \\
\hline $11-20$ & 23.5 \\
\hline Mean & 8 \\
\hline
\end{tabular}

Extension visits were low since up to $43 \%$ of the respondents were not visited within the last one year while half (50\%) had just one visit and about $7 \%$ had 2 visits (Table 1 ). The average extension visit to the respondents was once in a year. This indicates that extension service delivery is far below the recommended schedules as Salau et al. (2012) reported that the recommended visit schedules of village extension agents under the T\&V system is two extension visit per month. On the average, the women have been engaged in groundnut processing for 13 years indicating that they have many years of processing experience. This could have positive implication for the business as it is expected that the higher the women's years of experience the better their productive capacity because of the knowledge accumulated over the years. 
Creative commons User License: CC BY-NC-ND

Abstracted by: EBSCOhost, Electronic Journals Service (EJS),

Google Scholar, Journal Seek, Scientific Commons,

Food and Agricultural Organization (FAO), CABI and Scopus
Journal of Agricultural Extension

Vol. 22 (2) June, 2018

ISSN(e): 24086851; ISSN(Print); $1119944 X$

http://journal.aesonnigeria.org

http://www.ajol.info/index.php/jae

Email: editorinchief@aesonnigeria.org

About $90 \%$ of women had no access to credit to finance their activities in the last five years. Sheheli, 2012 similarly revealed that majority of women in micro-enterprising do not have access to credit. Above $80 \%$ of the respondents belong to one cooperative association or the other with varying years of membership ranging from 1 year to 20 years. This implies that it will be easy to reach the women in groups for purposes of information dissemination and new women's empowerment programmes that may be introduced in the area.

\section{Factors Influencing Level of Profit of Women Groundnut Processors}

Table 2 shows that the R-square value was 0.546 indicating that $54.6 \%$ of the variation in household income could be accounted for by the combined effect of the variables included in the model while the other $45.4 \%$ remained unexplained. The adjusted Rsquare also supported the claim with a value of 0.499 or $49.9 \%$. It implies that the independent variables explain the change in the dependent variables at $49.9 \%$ level of confidence. The model was well fitted to the data since the F-ratio value (11.602) was highly significant $(P<0.01)$. This implies that the joint effects of all the included variables influence on the income of the beneficiaries and the regression result was statistically reliable. The results of the regression analysis indicate that age, household size, dependency, years of formal schooling, years of membership in cooperative societies, nature of involvement in enterprise, ownership structure and access to market significantly influenced the level of profit from the activity (Table 2). The details of this influence are described below.

Table 2: Factors influencing level of profit of women groundnut processors

\begin{tabular}{|c|c|c|c|}
\hline Variables & Coefficients & Std. Error & t-value \\
\hline Constant & 12042.287 & 12172.122 & 0.989 \\
\hline $\operatorname{Age}\left(X_{1}\right)$ & 165.822 & 81.894 & $2.025^{\star \star}$ \\
\hline Years of formal education $\left(\mathrm{X}_{2}\right)$ & -2016.520 & 428.073 & $4.711^{* * *}$ \\
\hline Household size $\left(X_{3}\right)$ & 464.540 & 155.676 & $2.984^{* * *}$ \\
\hline Marital status $\left(X_{4}\right)$ & -1355.099 & 9099.882 & -0.149 \\
\hline Headship status $\left(X_{5}\right)$ & 2913.374 & 4725.765 & 0.616 \\
\hline Number of extension visits $\left(\mathrm{X}_{6}\right)$ & 632.422 & 1485.624 & 0.426 \\
\hline Years of experience $\left(X_{7}\right)$ & -44.469 & 215.83 & -0.206 \\
\hline Amount of $\operatorname{credit}\left(X_{8}\right)$ & 0.074 & 0.126 & 0.585 \\
\hline Years of membership in cooperative societies $\left(X_{9}\right)$ & 610.86 & 312.009 & $1.958^{*}$ \\
\hline Nature of involvement $\left(\mathrm{X}_{10}\right)$ & 5002.815 & 1853.771 & $2.699^{\star \star *}$ \\
\hline Ownership structure $\left(\mathrm{X}_{11}\right)$ & -5064.77 & 2413.046 & $-2.099^{* *}$ \\
\hline Number of assistants $\left(\mathrm{X}_{12}\right)$ & -59.939 & 822.682 & -0.073 \\
\hline Market access $\left(\mathrm{X}_{13}\right)$ & 3009.693 & 1420.377 & $2.119^{\star *}$ \\
\hline \multicolumn{4}{|l|}{$R^{2}=0.546 ; R^{-2} A d j=0.499$} \\
\hline F-ratio $=11.602^{* * *}$ & & & \\
\hline
\end{tabular}


Creative commons User License: CC BY-NC-ND

Abstracted by: EBSCOhost, Electronic Journals Service (EJS),

Google Scholar, Journal Seek, Scientific Commons,

Food and Agricultural Organization (FAO), CABI and Scopus
Journal of Agricultural Extension

Vol. 22 (2) June, 2018

ISSN(e): 24086851; ISSN(Print); 1119944X

http://journal.aesonnigeria.org

http://www.ajol.info/index.php/jae

Email: editorinchief@aesonnigeria.org

\section{Age}

Age of the women processors had positive relationship with their income with a coefficient value of $165.82(\mathrm{P}<0.05)$. The result indicates that the profit increases with increase in age. This indicates that women's profit increases by $\mathrm{N165.82}$ with every oneyear increase in their age. The result is similar to that of Rahman (2006) where it was found that age has significant and positive effect on women's income. Age is a major socio-economic factor that significantly affects the performance of individuals in any activity. Thus, the low income at early age by the women processors might be related to the demands of child bearing and rearing, taking care of husbands and other family members, which prevents rural women from getting fully engaged in income generating activities. Sheheli (2012) found higher participation of middle-aged women in income generating activities (implying more income) compared to old women. However, Kudi et al. (2009) and Lhing et al. (2013) found a negative relationship between age of their respondents and their income.

\section{Household size}

A significant positive relationship was found between the women's household size and their profit. This implies that as the household size increases, the profit will also increase. The women's income increased by $\$ 464.54$ with an increase of one family member. Groundnut processing is a highly labour intensive venture and a large household has the opportunity of providing free family labour (as labour constitutes the second largest percentage of total variable cost), thereby reducing cost incurred in the business.

\section{Years spent in formal schooling}

The regression results are somewhat contrary to expectation because years of formal schooling for the women was found to have a significant $(P<0.01)$ but negative influence on the women's profit. This means that an increase in years of formal school of the beneficiaries leads to a decrease in profit realized. The implication is that for every additional year spent in formal schooling by the women, $\$ 2,016.52$ of her income will be reduced. The expectation is that increase in formal schooling will lead to an increase in income since educated women are more likely to have better managerial skills which will enhance profit from the processing activity resulting to increased income. The possible explanation could be that the processors do not put into practice what they have learnt in formal schooling. The findings contradict the findings of Oluwasola (2010) who studied the stimulation of rural employment and income for cassava processing farming households in Oyo State, Nigeria. The author found that a unit increase in the level of education increased the net income of clients by $29.5 \%$.

\section{Years of membership in cooperative societies}

The coefficient for years of cooperative membership (610.86) was positive and significant at $10 \%$ level of probability. This relationship implies that the profit increase with increase in years of membership of cooperatives. Thus, participation of women processors in cooperative societies positively contributes to income. This is because participation in cooperative societies provides an avenue for access to information among the women, 
Creative commons User License: CC BY-NC-ND

Abstracted by: EBSCOhost, Electronic Journals Service (EJS),

Google Scholar, Journal Seek, Scientific Commons,

Food and Agricultural Organization (FAO), CABI and Scopus
Journal of Agricultural Extension

Vol. 22 (2) June, 2018

ISSN(e): 24086851; ISSN(Print); 1119944X

http://journal.aesonnigeria.org

http://www.ajol.info/index.php/jae

Email: editorinchief@aesonnigeria.org

thereby enhancing diffusion of any innovations and improvement in their production. A study by Rahman and Naoroze (2007) has similarly revealed that rural women's participation in cooperative societies for income generation allows them to gain more control of the economic and social returns.

\section{Ownership structure}

The ownership structure of the groundnut processors also influenced the profit of the women processors. A significant but negative relationship $(\beta=-5064.77, p<0.05)$ was however, recorded between this variable and profit. The implication of the relationship is that the profit of women processors increases as the women move from being sole owners of their businesses to being in partnership. The reason could be that the contribution of ideas and/or capital by more than one party together helps increase profit released from the activity. When there is more than one woman in a business, the different partners will each give their contribution either financially or otherwise. For example, when one partner has limited funds to contribute, another partner may have. These could positively influence their enterprise, consequently increasing their profit.

\section{Nature of involvement in processing}

A significant and positive relationship $(\beta=5002.815, P<0.01)$ was observed between the women's nature of involvement in processing business and the profit from the activity. This means that as the women move from being in the business in part-time to full-time basis, their income will increase. A possible reason for this could be that as full-time operators in their enterprises, the women are more committed and more focused on their businesses than part-time entrepreneurs that may have other activities needing their attention them from the businesses. More commitment could mean more profit, which will consequently enhance profit.

\section{Market access}

Access to groundnut product market had significant and positive influence on profit $(\beta=$ 3009.693, $\mathrm{P}<0.05)$. This means that the higher the access to market, the more the profit. This is in accordance with a priori expectations. When women have easy access to markets where their products will easily be sold off at good prices, they will be able to easily go into the next cycle of production thereby increasing total monthly revenue earned from the enterprise. All things being equal, this could mean increased income.

\section{Major Constraints Encountered by Women Groundnut Processors}

The most prominent constraints faced by women in groundnut processing as shown in Table 3 were inadequate capital $(97 \%)$, high cost of raw material $(91 \%)$, limited access to credit (88\%) and inadequate extension services (85\%). Women are constrained by poverty and do not have capital for starting or even running their businesses (Okoli and Umeh, 2001). The finding is a common characteristic of most enterprises that are ran by rural women especially when compared with their male counterpart. Many studies (Haruna et al., 2006; Ibrahim et al., 2010; Sani and Danwanka, 2011) confirm this finding 
Creative commons User License: CC BY-NC-ND

Abstracted by: EBSCOhost, Electronic Journals Service (EJS),

Google Scholar, Journal Seek, Scientific Commons,

Food and Agricultural Organization (FAO), CABI and Scopus
Journal of Agricultural Extension

Vol. 22 (2) June, 2018

ISSN(e): 24086851; ISSN(Print); 1119944X

http://journal.aesonnigeria.org

http://www.ajol.info/index.php/jae

Email: editorinchief@aesonnigeria.org

in separate studies. High cost of raw materials is another major constraint associated with groundnut processing in the study area. The respondents attested that the major raw material in groundnut processing enterprise (raw groundnut) is very expensive in spite of the fact that Kano State is a major producing area of raw groundnut. The finding was confirmed by the findings of Iliyasu et al. (2008). Women face a number of barriers to obtaining credit. Property that is acceptable as collateral, especially land is usually held by men and formal financial institutions often deem the types of valuable held by women unacceptable (Quisumbing et al., 1995).

Table 3: Major constraints encountered by women groundnut processors Constraints Percentage*

Inadequate capital

Limited extension contacts

High cost of raw material

Poor working condition

Inadequate access to credit

Poor marketing facilities and opportunities
97.32

82.21

91.28

73.83

87.58

59.73

*Multiple responses

\section{Conclusion and Recommendations}

Groundnut processing into oil and cake is profitable though constrained by inadequate capital, high cost of raw material and inadequate access to credit. Factors that significantly influence level of profit realized by the women were age, household size, years of formal schooling, years of membership in cooperative nature of involvement in enterprise ownership structure and market access. Women should be encouraged to form cooperatives for better access to credit, improved equipment, information and other extension benefits on groundnut processing so as to enhance the ease of production; there is need for linkages with financial institutions by their respective cooperatives so as to provide loans to these women who are resource poor to improve their capital base and take advantage of large scales production; and, there is need for proper marketing outlet for the products of these women so as to enhance their standard of living through increase in productivity and profitability.

\section{References}

Abdullah, N., Kedah, S., Hassan, K., and Yusof, R. (2014). A preliminary study of rural women entrepreneurs: Characteristics and business success factors. International Review of Social Sciences and Humanities, 7(2): 172-181. 
Creative commons User License: CC BY-NC-ND

Abstracted by: EBSCOhost, Electronic Journals Service (EJS),

Google Scholar, Journal Seek, Scientific Commons,

Food and Agricultural Organization (FAO), CABI and Scopus
Journal of Agricultural Extension

Vol. 22 (2) June, 2018

ISSN(e): 24086851; ISSN(Print); 1119944X

http://journal.aesonnigeria.org

http://www.ajol.info/index.php/jae

Email: editorinchief@aesonnigeria.org

Abonge, C. V. (2012). Assessing the impact of women's enterprises on household livelihoods and survival: Evidence from the North West Region of Cameroon. Greener Journal of Social Sciences, 2(5):147-159.

Consultative Group on International Agricultural Research, CGIAR (2005). Research and impact. Retrieved on 18/1/11 from www.cgiar org/impact/research/groundnut.html

Danwanka, H.A., lliyasu, A.Y. and Isa, M. (2005). Economics of local extraction of oil from groundnut in Bauchi Metropolis. Journal of League of Researchers in Nigeria, 6(1):57-60

Food and Agriculture Organisation, FAO (2009). Production Year Book, Vol. 60.

Food and Agriculture Organisation Statistics, FAOSTAT (2011) FAO Statistics Division 2013 [http://faostat.fao.org/site/567/, site visited on 27/01/2013.

Girei, A. A., Dauna, Y. and Dire, B. (2013). An economic analysis of groundnut (Arachis hypogea) production in Hong Local Government Area of Adamawa State, Nigeria. Journal of Agricultural and Crop Research, 1(6):84-89.

Girei, A. A., Audu, S. I., Onuk, E. G. and Ismail, Z.M. (2016).Why the economics of groundnut processing in Akwanga local government area, Nasarawa State, Nigeria. Scientific Papers Series Management, Economic Engineering in Agriculture and Rural Development, 16(4):103-110.

Haruna, U., Murtala, N. and Ahmed, H. S. (2006). Economics of groundnut processing among the rural women in Katagun local government area Bauchi state, Nigeria. Savannah Journal of Agriculture, 1(2):138-144.

Ibrahim, D. B., Dutse, A. Y. and Hamidu, B. M. (2005). Assessment of awareness level of air and noise pollution of car transport among Motorist in Bauchi metropolis. Management Network Journal, 3(6): 26-35.

Ibrahim, H., Y., Saingbe, N., D., and Ibrahim, H., I. (2010): An evaluation of groundnut processing by women in a rural area of North Central Nigeria. Journal of Agricultural Sciences (2)1.206-212.

lliyasu, A., Wulet, I. and Yusuf, K. (2008). Profitability analysis of groundnut processing in Maiduguri Metropolitan Council of Borno State, Nigeria. Nigerian Jounal of Basic and Applied Sciences, 16(2):253-256.

International Crops Research Institute for Semi-arid Tropics (ICRISAT) (2011). Rebuilding the groundnut pyramids: A partnership approach to accelerated groundnut improvement in Nigeria. Research proposal prepared in partnership with IAR, Samaru, submitted to ICRISAT Management, September, 2005, pp13. 
Creative commons User License: CC BY-NC-ND

Abstracted by: EBSCOhost, Electronic Journals Service (EJS),

Google Scholar, Journal Seek, Scientific Commons,

Food and Agricultural Organization (FAO), CABI and Scopus
Journal of Agricultural Extension

Vol. 22 (2) June, 2018

ISSN(e): 24086851; ISSN(Print); $1119944 X$

http://journal.aesonnigeria.org

http://www.ajol.info/index.php/iae

Email: editorinchief@aesonnigeria.org

Jamilu, A. A., Haruna, S. K.,Abdullahi, A. Y. and Baba, D. (2014). Effects of youth participation in guava production on poverty alleviation in two selected areas of Kaduna State. Conference Proceedings of $19^{\text {th }}$ Annual National Conference of the Agricultural Extension Society of Nigeria held at the Federal University of Agriculture, Owerri, Imo State, $27^{\text {th }}-30^{\text {th }}$ April, 2014pp: 110-118.

Kudi, T. M., Odugbo, S. B., Banta, A. L. and Hassan, M. B. (2009). Impact of UNDP microfinance programme on poverty alleviation among farmers in selected local government areas of Kaduna State, Nigeria. International Journal of Sociology and Anthropology, 1(6): 099-103.

Lhing, N. N., Nanseki, T. and Takeuchi, S. (2013). An analysis of factors influencing household income: A case study of PACT microfinance in Kyaukpadaung township of Myanmar. American Journal of Human Ecology, 2(2): 94-102. DOI: $10.11634 / 216796221302320$

Muhammad-Lawal, A., Animashaun, J. O. and Towoju, A. S. (2012). Economics of smallscale agro-enterprises in Nigeria: A case study of groundnut processing among rural women in Kwara State. Journal of Sustainable Development in Africa, 14(5):54-64.

National Population Commission, 2006, National Population Census

Nnamdi, A.E (2010) "Groundnut processing and trading in Nigeria" retrieved on $18 / 1 / 11$ from http://www.articlebase.com/business-opportunities-articles/groundnut-processingand-trading-in-nigeria-3923801.html

Nwosu, I. E. and Okon, D. P. (2013). Assessment of the impact of palm oil processing on the livelihood of rural women in Ika Local Government Area, Akwa Ibom State. Nigeria. Journal of Agriculture and Social Science, 9:11-14

Okoli, P.I. and Umeh, C. D. (2001). Food security and women in developing countries. Ahfad journal (accessed December 4, 2008)

http://findarticles.com/particles/mi-hb003/is-2-218/ai-n28892480/pg-18?tag=arBody;Col 1 .

Oluwasola, O. (2010). Stimulating rural employment and income for cassava processing farming households in Oyo State, Nigeria, Journal of Development and Agricultural Economics, 2(2):018-025.

Practical Action (2010). Sustainable livelihood through agro processing" retrieved on 18/1/11 from http://practicalaction.org/food-production/agroprocessing 
Creative commons User License: CC BY-NC-ND

Abstracted by: EBSCOhost, Electronic Journals Service (EJS),

Google Scholar, Journal Seek, Scientific Commons,

Food and Agricultural Organization (FAO), CABI and Scopus
Journal of Agricultural Extension

Vol. 22 (2) June, 2018

ISSN(e): 24086851; ISSN(Print); $1119944 X$

http://journal.aesonnigeria.org

http://www.ajol.info/index.php/iae

Email: editorinchief@aesonnigeria.org

Quisumbing A.R., Brown, L. R., Feldstein, H. S., Haddad, L. and Pena, C. (1995). Women: The key to food security. IFPRI: food policy report. Washington, D.C. 22pp (accessed December 5, 2008)

http://www.ifpri.org/pubs/fps/fps21.htm

Rahman, M. H. (2006). Empowerment of Landless Rural Women through Income Generating Activities under SAIP of DAE. MS Thesis. Department of Agricultural Extension Education, Bangladesh Agricultural University, Mymensingh, Bangladesh.

Rahman, M. H. and Naoroze, K. (2007). Women Empowerment through Participation in Aquaculture: Experience of a Large-scale Technology Demonstration Project in Bangladesh. Journal of Social Science, 3(4): 164-171.

Salau, E. S., Onuk, E. G. and Ibrahim, A. (2012). Knowledge, perception and adaptation strategies to climate change among farmers in Southern Agricultural Zone of Nasarawa State, Nigeria. Journal of Agricultural Extension, 16(2):199-211.

Sani, M. H. and Danwanka, H. (2011). Economic analysis of women soap making agribusiness enterprises and family sustenance in Kogi State, Nigeria. Asian Journal of Rural Development, 1:54-62.

Sheheli, S. (2012). Improving Livelihood of Rural Women through Income Generating Activities in Bangladesh. A Dissertation submitted to Division of Agricultural Economics, Humboldt University, Berlin in Fulfilment for Degree of Doctor of Philosophy.

Taphee, G.B. and Jongur, A.A.U. (2014). Productivity efficiency of groundnut farming in northern Taraba State, Nigeria. Journal of Agriculture and Sustainability, 5(1): 4556. 